\title{
DESKRIPSI PENGELOLAAN SAMPAH MEDIS DI RUMAH SAKIT UMUM DAERAH KRT.SETJONEGORO WONOSOBO TAHUN 2016
}

\author{
Aprilia Indah Setyaningrum ${ }^{1)}$, Zaeni Budiono ${ }^{2)}$ \\ Jurusan Kesehatan Lingkungan, Politeknik Kesehatan Kemenkes Semarang \\ Jl.Raya Baturaden KM.12 Purwokerto, Indonesia
}

\begin{abstract}
Abstrak
RSUD KRT Setjonegoro Wonosobo merupakanrumah sakit milik pemerintah kabupaten Wonosobo dan merupakan salah satu rumahsakit yang menghasilkan sampah medis dari setiap kegiatan medis didalam rumahsakit. Tujuan penelitian ini adalah untuk mengetahui pengelolaan sampah medis diRSUD KRT Setjonegoro Wonosobo.Metode penelitian menggunakan penelitian deskriptif yangmenggambarkan tentang pengelolaan sampah medis di RSUD KRT SetjonegoroWonosobo. Penelitian dilakukan dengan cara observasi langsung mengenai pengelolaan sampah medis di RSUD KRT Setjonegoro Wonosobo. Hasil penelitian rata-rata volume sampah medis RSUD KRT Setjonegoro perharinya adalah 630,6liter/hari dengan rata-rata berat sampah medis per harinyaadalah79,08kg/hari, dalam pengelolaan sampah medis tersebut masih adayang belum sesuai dengan peraturan, seperti pengangkut sampah medis yang tidak rutin, tidak dilakukan pencucian dan pemberian desinfektan, masih adanya sampah non medis yang tercampur kedalam sampah medis. Berdasarkan uraian diatas dapat disimpulkan bahwapengelolaan sampah medis di RSUD KRT Setjonegoro masih ada yang belum sesuai standar yaitu pada fase pewadahan belum dilakukan pencucian tempat sampah secara rutin dan waktu pengangkutan yang tidak tentu. Disarankan bagi penanggung jawab sampah medis dalam hal waktu pengangkutan agar lebih dipantau, bagi petugas pelaksana limbah tempat sampah/troli yang habis digunakan dicuci dan didesinfeksi, bagi tenaga medis rumah sakit diharapkan membuang sampah sesuai dengan jenisnya pada tempat sampah yang telah disediakan.
\end{abstract}

Kata Kunci : pengelolaan, sampah medis, rumah sakit

\section{PENDAHULUAN}

Rumah sakit merupakan salah satu penyelenggara pelayanan publik. Dalam pelaksanaan pelayanan kesehatan berpotensi menghasilkan sampah. Sampah merupakan sisa kegiatan sehari-hari manusia. Sampah rumah sakit tersebut dapat berupa sampah bahan berbahaya, beracun karena sifat, konsentrasinya atau jumlahnya dapat membahayakan bagi kesehatan maupun lingkungan. Apabila tidak tertangani dengan baik, sampah medis rumah sakit dapat menimbulkan masalah baik dari aspek pelayanan maupun estetika, bahkan juga menjadi penyebab pencemaran lingkungan dan sumber penyakit (infeksi Nosokomial). Tahun 2000 WHO mencatat kasus infeksi akibat tusukan jarum yang terkontaminasi virus seperti terinfeksi virus Hepatitis B sebanyak 21 juta (32\% dari semua infeksi baru), terinveksi virus Hepatitis C sebanyak 2 juta (40\% dari semua infeksi baru), terinfeksi HIV sebanyak 260 ribu (5\% dari seluruh infeksi baru). Jumlah penderita Hepatitis B dan C di Indonesia sendiri diperkirakan mencapai 30 juta orang. Sekitar 15 juta orang dari penderita.

Hepatitis B dan C berpotensi menderita chronic liver disease. Indonesiadigolongkan ke dalam kelompok daerah dengan prevalensi hepatitis B dengan tingkat endemisitas menengah sampai tinggi dari total sebanyak 5.870 kasus hepatitis di Indonesia berdasarkan hasil pendataan tahap pertama vang

1) Email : aiendah87@gmail.com

2) Email : pakzaeni@gmail.com dilakukan Oktober 2007 hingga 9 September 2008, $40 \%$ di antaranya berasal dari pengguna jarum suntik.Tujuan penelitian ini adalah untuk mengetahui pengelolaan sampah medis diRSUD KRT Setjonegoro Wonosobo.

\section{BAHAN DAN METODE}

Penelitian ini dilaksanakan RSUD KRT Setjonegoro Wonosobo Jalan RSU No.1 Kabupaten Wonosobo. Subyek penelitian ini adalah pengelolaan sampah medis di RSUD KRT Setjonegoro Wonosobo.Jenis data yang dkumpulkan meliputu data umum berupa kondisi RSUD KRT Setjonegoro Wonosobo, kapasitas tempat tidur, jumlah pasien, fasilitas pelayanan, struktur organisasi, data khusus berupa proses pengelolaan sampah medis mulai dari penimbulan sampah, pewadahan sampah, pengumpulan sampah, pengangkutan sampah.

Sumber data meliputi data primer yang diperoleh melalui pengamatan langsung dan wawancara, data sekunder diperoleh dari pegawai yang bekerja dibagian umum RSUD KRT Setjonegoro Wonosobo. Pengumpulan Data dengan cara wawancara dan observasi secara langsung. Cara analisis data yang dipakai yaitu analisis univariat, karena hanya menggunakan satu variabel yaitu menggambarkan hasil penelitian dengan analisis tabel.

\section{HASIL DAN PEMBAHASAN}


1. Penimbulan Sampah Medis

Ruangan yang menghasilkan sampah medis dirumah sakit diantaranya ruang Anggrek, Bougenville, Cempaka, Dahlia, Edelweis, Flamboyan, IBS, ICU, IGD, VK / bersalin, BBRT, dan Poliklinik. Jenis-jenis sampah medis yang dihasilkan di RSUD KRT Setjonegoro Wonosobo adalah

a. Sampah benda tajam yang dihasilkan, yaitu jarum suntik,pecahan botol obat, jarum infus.

b. Sampah infeksiusyang dihasilkan, yaitu slang infus, perbanluka, botol infus, jarum suntik, sarung tangan disposable, linenpasien yang terkenainfeksi.

c. Sampah jaringan tubuh yang dihasilkan yaitu potongan tubuhbekas operasi dan darah.

d. Sampah sitotoksisyang dihasilkan yaitu sisa obat yangdigunakan untuk terapi.

Proses penimbulan sampah medis rumah sakit mempunyai rata-ratavolumesampah medis yang diihasilkan yaitu 630,6 liter/hari sedangkan rata-rataberatsampah medis yang dihasilkan yaitu 79,08 kg/hari.

Permasalahan pada penimbulan yaitu masih adanya sampah non medis yang tercampurpada tempat sampah medis seperti: botol minuman, kertas, dan tisu. Permasalahan pada proses penimbunan tersebut perlu ditangani lebih baik misalnyadengan cara melakukan penyuluhan kepada tenaga kerja medis/non medisdirumah sakit tentang pemisahan sampah medis dannon medis sehinggavolume dan biaya pemusnahan sampah tidak bertambah banyak.

2. Pewadahan Sampah Medis

Pewadahan sampah medis yang terdapat di setiap ruangan penghasilsampah medis terbuat dari bahan yang kuat, cukup ringan, tahan karat, antibocor, anti tusuk, kedap air. Wadah tempat sampah medis menggunakankantong plastik berwarna kuning dan diganti setiap hari, untuk sampah medis bendatajam seperti jarum suntik, spuit, silet bedah masuk kedalam safety box.

Tempat pewadahan sampah medis menurut Kepmenkes No. 1204/ Menkes/SK/X/2004 :

a. Terbuat dari bahan yang kuat, cukup ringan, tahan karat, kedap air, dan mempunyai permukaan yang halus pada bagian dalamnya, misalnya fiberglass.

b. Di setiap sumber penghasil sampah medis harus tersedia tempat pewadahan yang terpisah dengan sampah non medis.

c. Kantong plastik diangkat setiap hari atau kurang sehari apabila 2/3 bagian telah terisi penuh.

d. Benda-benda tajam hendaknya ditampung pada tempat khusus (safety box) seperti botol atau karton yang aman. e. Tempat pewadahan limbah medis infeksius dan sitotoksik yang tidak langsung kontak dengan sampah harus segera dibersihkan dengan larutan desinfektan apabila akan dipergunakan kembali, sedangkan untuk kantong plastik yang telah dipakai dan kontak langsung dengan sampah tersebut tidak boleh digunakan lagi.

Permasalahan pada proses pewadahan yang perlu segera ditangani dengan baik misalnya mengganti kantong plastik sesuai dengan standar yang berlaku dan diangkut setiap hari.

3. Pengumpulan Sampah Medis

Pengumpulan sampah medis dilakukan oleh petugas pelaksana limbah sebanyak dua kali sehari yaitu pada pagi dan siang hari. Pengumpulan sampah medis berada di tempat pengumpulan sementara sebelum selanjutnya diambil oleh pihak ketiga untuk dimusnahkan sesuai dengan peraturan yang berlaku. Bangunan/tempat pengumpulan sampah medis kedap air dan lokasi pengumpulan sampah medis bebas banjir dan serta mempunyai atap.

Permasalahan yang ada pada proses pengumpulan yaitu waktu pengumpulan yang kadang tidak sesuai dengan jadwal seperti yang seharusnya diambil dua kali sehari namun hanya sekali sehari, petugas pengambil yang hanya berjumlah satu orang juga menjadi alasan kenapa waktu pengambilanya menjadi tidak rutin, juga pihak ketiga yang kadang telat dalam mengambil sampah sehingga tak jarang sampah sampai menumpuk di tempat penampungan sementara.

4. Pengangkutan Sampah Medis

Proses pengangkutan sampah medis menggunakan gerobak yangdigunakan khusus untuk mengangkut sampah medis, gerobak sampah medisyang digunakan mudah dibersihkan, tidak ada tepi tajam yang dapat merusakkantong plastik selama proses pengangkutan, mudah dimuat dan dibongkarmuat. Gerobak yang digunakan masih dalam keadaan baik dan tertutup.Gerobak sampah medis yang digunakan tidak rutin dicuci setiap hari. Pengangkutan sampah medisdilakukan dua kali dalam sehari, pengangkutan dilakukan dengan caramengambil kantong plastik berwarna kuning dari tempat sampah medis yangberada disetiap ruangan penghasil sampah medis khususnya ruang perawatan dan dituangkan ke gerobaksampah medis.

Menurut Kepmenkes RI No 1204 tahun 2004 menjelaskan bahwaperaturan transportasi sampah medis yang tepat yaitu :

a. Kantong limbah medis sebelum dimasukkan ke kendaraan pengangkutharus diletakkan dalam container yang kuat dan tertutup 
b. Pengangkutan limbah keluar rumah sakit menggunakan kendaraan khusus

c. Kantong limbah medis harus aman dari jangkauan manusia maupunbinatang

d. Petugas yang menangani limbah harus menggunakan APD

5. Struktur Organisasi

Organisasi pelaksana limbah terdiri dari 4 orang yaitu satu orang koordinator/kepala instalasi sanitasi dan loundry dan tiga orang pelaksana limbah. Tidak terdapat struktur organisasikhusus pengelolaan sampah medis, struktur organisasi tercantum padainstalasi sanitasi dan loundry.

6. Dana Pengelolaan Sampah Medis

Dana kegiatan atau kebutuhan dalam pengelolaan sampah medis setiap bulan di RSUD KRT Setjonegoro tercantum dalam DPA (Daftar Pengguna Anggaran) digunakan untuk membayar pihak ketiga dalam pemusnahan samph medis, untuk perkilonya sampah medis harus membayar Rp 12.000,00. Jumlah sampah minimal dalam sekali angkut yaitu 430 kg, pengangkutan dilakukan tiga kali seminggu sehingga total sampah yang diangkut dalam seminggu yaitu $1.290 \mathrm{~kg}$. Biaya yang diperlukan dalam seminggu yaitu 1.290 dikali Rp. 12.000,00 yaitu Rp 15.480.000,00 jika dikalikan sebulan maka diperlukan dana sebesar Rp. 61.920.000,00 yang minimal harus pihak rumah sakit keluarkan kepada pihak ketiga setiap bulannya. Sejauh ini anggaran yang dikeluarkan oleh pihak rumah sakit masih dapat memenuhi kebutuhan yang diperlukan untuk penanganan sampah medis dengan pihak ketiga.

Pendanaan dana yang berasal dari sektor swasta atau beberapatingkat pemerintahan. Untuk instansi kesehatan milik pemerintah,pemerintah dapat menggunakan pedapatan negara untuk membiayaisistem pengelolaan smapah medis rumah sakit, sedangkan untuk instansi swasta, pemerintah dapat memberlakukan kebijakan langsungyang mewajibkan swasta untuk menerapkan sistem pengelolaansampah medis sendiri dan mendesak mereka unruk menggunakansarana umum.

\section{KESIMPULAN}

Penimbulan sampah medis di RSUD KRT Setjonegoro Wonosobo berasal dari ruang perawatan Anggrek, Bougenville, Cempaka, Dahlia, Edelweis, Flamboyan, Poliklinik, IBS, ICU, IGD, VK, dan BBRT., masih ada sampah non medisyang tercampur pada tempat sampah medis.

Pewadahan tempat sampah medis di rumah sakit ini mempunyai jumlahtempat sampah medis sejumlah 24 buah dengan volume masing-masingtempat sampah 60 liter, pencucian wadah tempat sampah medis tidak dilakukan setiap hari.

Pengumpulan sampah medis dilakukan setiap hari dari setiap ruanganpenghasil sampah medis dan dikumpulkan ke TPS menggunakan trolidorong, sampah medis infeksius dilapisi kantong plastik berwarnakuning dan safetybox untuk sampah medis benda tajam.

Pengangkutan sampah medis dilakukan setiap hari menggunakan trolidorongkhusus sampah medis dan pengangkutan dilakukan dua kalidalam sehari namun waktunya tidak tentu.

RSUD KRT. Setjonegoro Wonosobo tidak ada struktur organisasi khususuntuk faktor penunjang pengelolaan sampah medis.

Biaya operasional RSUD KRT. Setjonegoro Wonosobountukfaktor penunjang sampah medis, tercantum dalam Daftar PenggunaAnggaran (DPA).

\section{DAFTAR PUSTAKA}

Boy Subirosa S. 2011. Sanitasi Air dan Limbah Pendukung Keselamatan Pasien Rumah Sakit. Jakarta: Salemba Medika.

Departeman Kesehatan RI, 1996. Pedoman Teknis Pengelolaan Limbah Klinis dan Desinfeksi \& Sterilisasi di Rumah Sakit. Jakarta: Depkes RI.

Departemen Kesehatan RI Direktorat Jenderal Pemberantasan Penyakit Menular dan Penyehatan Lingkungan Pemukiman (PPM \& PLP) dan World Health Organization (WHO), 1991, Pedoman Pegelolaan Limbah Klinis. Jakarta: DIT.JEN.PPM \& PLP dan WHO

Keputusan Menteri Kesehatan Republik Indonesia Nomor 1204/MENKES/SK/X/2004 tentang PersyaratanKesehatan Lingkungan Rumah Sakit

Maimunah. 2002. Gambaran PerilakuPetugas Rumah Sakit Terhadap Sistem Pengelolaan Sampah Medis di Rumah Sakit Kusta Sinacang Belawan tahun 2002. Skripsi: Universitas Sumatera Utara

Muchsin Alatas. 2013. Gambaran Perilaku Perawat dalam Membuang Limbah Medis dan Non Medis di Rumah Sakit Umum Daerah Kabupaten Aceh TamiangTahun 2013. Skripsi: Universitas Sumatera Utara

Pruss A. Giroult. G, Ruslibrook. P, 2005, Pengelolaan Aman Limbah Layanan.Kesehatan, Jakarta: EGC 
Puri Wulandari. 2012. Upaya Minimisasi dan Pengelolaan Limbah Medis di Rumah Sakit Haji Jakarta Tahun 2011. Skripsi: Universitas Indonesia

Rahma Febrina. 2011. Sistem Pengelolaan Sampah Padat di Rumah Sakit X Jakarta Tahun 2011. Skripsi: Universitas Indonesia

Soekidjo Notoatmodjo. 2005. Metodologi Penelitian Kesehatan, Edisi Revisi 3.Jakarta: PT. Rineka Cipta

Suharsimi Arikunto. 2006. Prosedur Penelitian Suatu Pendekatan Praktik, Edisi Revisi VI. Jakarta: Rineka Cipta

World Health Organization (WHO), 2005. Pengelolaan Aman Limbah Layanan Kesehatan. Jakarta: Penerbit Buku Kedokteran 